\title{
A SEMANA DE 22 E A POESIA: CONTRADIÇÕES E DESDOBRAMENTOS
}

\author{
Leandro Pasini \\ lepasini@yahoo.com.br
}

Même s'il est vrai qu'il n'y a rien de nouveau sous le soleil, il ne consent point à ne pas approfondir ce qui n'est pas nouveau sous le soleil. Apollinaire. L'Esprit nouveau et les Poètes.

Não se sabe quais foram exatamente os poemas lidos na Semana de Arte Moderna de 1922, mas são conhecidos os poetas que nela tomaram parte, seja diretamente, lendo suas próprias criações diante do público, seja indiretamente, cedendo suas produções para a leitura de outrem no palco do Teatro Municipal. O programa da Semana nos informa que, no primeiro dia de apresentações, 13 de fevereiro, Graça Aranha ilustra sua conferência "A emoção estética na arte moderna" com versos de Guilherme de Almeida e Ronald de Carvalho. No segundo dia, 15 de fevereiro, a palestra de Menotti del Picchia conta com poesias de Luís Aranha, Sérgio Milliet, Tácito de Almeida, Ribeiro Couto, Mário de Andrade, Plínio Salgado e Agenor Barbosa. Nesse mesmo dia, no intervalo, Mário faz uma palestra sobre arte moderna no saguão, apresentando, possivelmente, trechos de poemas de seus companheiros 
como exemplo da nova estética. O último dia, 17 de fevereiro, é dedicado exclusivamente à música (BATISTA; LOPEZ; LIMA, 1972, p. 395-398)1.

Nem todos esses nomes atuaram com o mesmo peso na "exemplificação" do que era a "novíssima” poesia. A proposta deste texto é inquirir de que modo a poesia tornada pública no contexto da Semana de 22 dialogava criticamente com as escolas poéticas que a precederam. Questiona-se, assim, sobre o tipo de influência que o quadro local, composto de supremacia parnasiana e Simbolismo marginalizado, exerceu na incorporação das estéticas das vanguardas internacionais. Nesse sentido, este texto também tem em vista os problemas específicos gerados pela relação entre a poesia que se modernizava e o dado local, a presença diferenciadora da realidade histórico-social brasileira. Pensemos, então, nos nomes que se apresentaram. Ribeiro Couto era o poeta penumbrista do Jardim das confidências (1921), que se modificou muito pouco ao contato com o Modernismo. Já Manuel Bandeira mudou muito, senão na sensibilidade, na dicção e na linguagem, no entanto, à época, ainda era o poeta igualmente penumbrista de Carnaval (1919), cujo poema "Os Sapos", sátira muito conhecida à poesia parnasiana, era uma arma de choque do primeiro Modernismo, mas não a grande portadora da renovação. Sérgio Milliet escrevia uma avançada, para o Brasil de então, poesia de vanguarda nos moldes de Blaise Cendrars, mas em língua francesa, o que tornava os seus poemas uma referência para a poesia brasileira, mas não a sua realização. Plínio Salgado, futuro líder do Integralismo, era então intelectual eclético e parcialmente curioso, o que o levou a escrever um "Canto Epitalâmico da Morte", de inflexão modernista, publicado por Menotti del Picchia em sua coluna do Correio Paulistano, em 1921.

Se Ribeiro Couto, Manuel Bandeira, Sérgio Milliet e Plínio Salgado, por motivos diferentes, não podiam ser considerados o eixo forte da renovação da poesia brasileira, já Guilherme de Almeida e Ronald de Carvalho puderam e foram, por Graça Aranha, apresentados como os grandes exemplos da poesia nova. Assim ele se expressa em sua palestra do dia 13:

${ }^{1 .}$ Há ligeiras modificações em programas enviados aos jornais de então ou distribuídos em locais de prestígio, como o Automóvel Clube. O cotejo dos programas pode ser feito em Boaventura (2008, p. 399-453) e Schwartz (2003). Quanto à poesia, as diferenças referem-se aos nomes de Álvaro Moreyra e Afonso Schmidt, anunciados em alguns programas, mas que não compareceram nem, ao que parece, foram recitados ou debatidos. 
Destes [poetas], libertados da tristeza, do lirismo e do formalismo, temos aqui uma plêiade. Basta que um deles cante, será uma poesia estranha, nova, alada e que se faz música para ser mais poesia. De dois deles, nesta promissora noite, ouvireis as derradeiras “imaginações”. Um é Guilherme de Almeida, o poeta de Messidor, cujo lirismo se destila sutil e fresco de uma longínqua e vaga nostalgia de amor, de sonho e de esperança, e que, sorrindo, se evola da longa e doce tristeza para nos dar nas Canções Gregas a magia de uma poesia mais livre do que a Arte. O outro é o meu Ronald de Carvalho, o poeta da epopeia da Luz Gloriosa, em que todo o dinamismo brasileiro se manifesta em uma fantasia de cores, de sons e de formas vivas e ardentes, maravilhoso jogo de sol que se torna poesia! A sua arte mais aérea agora, nos novos epigramas, não definha no frívolo virtuosismo que é o folguedo do artista. Ela vem de nossa alma, perdida no assombro do mundo, e é a vitória da cultura sobre o terror, e nos leva pela emoção de um verso, de uma imagem, de uma palavra, de um som à fusão do nosso ser no Todo infinito (ARANHA, 1969, p. 742-743).

Essas palavras de Graça Aranha estão vinculadas às ideias de seu livro $A$ estética da vida (1921), um tipo de abrasileiramento retórico do dionisíaco em Nietzsche, que defende que, por uma intuição estética, portadora de um furor enérgico e alegre, o homem deve superar o terror mítico da natureza e entregar-se a uma comunhão com um Todo infinito, que seria um tipo de transcendência cósmica. Daí vem o seu elogio à "magia" com que Guilherme de Almeida se liberta da nostalgia e da tristeza e ao dinamismo e à emoção de Ronald. Dadas as condições artísticas - a estagnação ornamental parnasiana e a timidez do regionalismo naturalista - do Brasil de 1921-1922, essa esquisita "filosofia" de Graça Aranha apresentava-se imbuída de certa demanda de liberdade estética. Essa demanda de liberdade, apresentada em termos atenuados, é também visível na poesia de Guilherme e Ronald. O que de mais novo produzia Guilherme de Almeida nesse momento foi recolhido em A frauta que eu perdi, publicado em 1924 e que, à época, se anunciava sob o título de Canções gregas. O que ele trazia de novo, para o público de então, eram as rimas irregulares ao longo do poema e, principalmente, o uso do verso polimétrico: "folhas mortas que acordais ao passo alípede das ninfas; / algas / lindas algas limpas" ("Epígrafe"). A ousadia era assim comentada por Oswald de Andrade: "Que dizem? Um verso de quinze sílabas perto de outro que só tem uma” (apud BRITO, 1997, p. 238). A mesma variedade no uso da rima e do metro distingue Ronald, que publicará, no ano da Semana, os seus Epigramas irônicos e sentimentais: "Poeta dos trópicos, / dá-me no teu copo de vidro colorido um gole d'água. / (Como é linda a paisagem no cristal de um copo d'água)", versos de "Interior" (CARVALHO, 1976, p. 168). Sobre esse poema escreve Mário de Andrade: “'Rima livre', variada, imprevista, irregular, muitas vezes ocorrendo no interior no verso" (ANDRADE, 1980, p. 229). Nesse caso, deve-se notar 
que a rima interna "vidro colorido" é mais rica que a rima "bárbara" de palavras homófonas "d'água".

Essas liberdades apresentadas pela poesia de Guilherme e Ronald estão vinculadas ao Penumbrismo, e não ao Modernismo, e foram percebidas como inovações porque, na história da poesia brasileira, o Simbolismo foi vencido pelo Parnasianismo e se tornou um movimento marginal e subterrâneo. Desse modo, as ousadias que se devem ao desenvolvimento da poesia simbolista: as sugestões vagas, a musicalidade evanescente, os ritmos frouxos e principalmente o último estágio de desagregação verbal e subjetiva do Simbolismo, o Penumbrismo, com seus meios-tons e meias-tintas, com seu verso polimétrico, suas rimas internas, sua inflexão coloquial na dicção e cotidiana na temática (GOLDSTEIN, 1983, passim) - toda a história interna da poesia simbolista aparecia ao público letrado de 1922 como novas ousadias e "futurismo". A ausência do Simbolismo como referência clara e objetiva para o leitor médio de poesia nesse momento, como veremos, foi um problema sentido pelos modernistas mais radicais, que buscaram criar formas específicas para superá-la. Contudo, no caso de Guilherme de Almeida e Ronald de Carvalho, seja pelas soluções de compromisso entre inovações penumbristas e tom artificioso e ornamental, seja pelos atestados de bons antecedentes, citados pelo próprio Graça Aranha, os livros Messidor e Luz gloriosa, o público do Teatro Municipal recebeu muito bem os poemas. Como se lê na Folha da Noite do dia 14 de fevereiro: “os Srs. Guilherme de Almeida e Ronald de Carvalho recitaram lindíssimas poesias, que foram longamente aplaudidas por toda a sala" (apud BOAVENTURA, 2008, p. 444).

A poesia de Ronald e de Guilherme, bem como, nesse momento, a de Ribeiro Couto e Manuel Bandeira, era mais uma força de transição do que de ruptura. O choque propriamente dito, a enunciação de coisas "inaceitáveis", que foram intensamente vaiadas pelo público, veio no dia 15, com a palestra de Menotti del Picchia, acompanhada de recitações dos poetas, e da conferência de Mário de Andrade no saguão durante o intervalo ${ }^{2}$. Menotti publicou sua palestra no Correio Paulistano em 17

2. Mário relembra esse dia em sua conferência sobre o Modernismo vinte anos depois: "Mas como tive coragem pra dizer versos diante duma vaia tão bulhenta que eu não escutava no palco o que Paulo Prado me gritava da primeira fila das poltronas?... Como pude fazer uma conferência sobre artes plásticas, na escadaria do Teatro, cercado de anônimos que me caçoavam e ofendiam a valer?..." (ANDRADE, 2002, p. 254). O jornal 
de fevereiro. Diferente do tom mais conciliador de Graça Aranha, a fala de Menotti é polêmica e provocadora. Embora fosse autor de prestígio, devido ao livro de versos Juca Mulato (1917), desde 1920 ele se batia nas páginas do Correio Paulistano, em que tinha uma crônica diária³, pela arte nova, em espírito de polêmica constante. Ao falar especificamente sobre a nova poesia, assim se expressa:

Queremos libertar a poesia do presídio canoro das fórmulas acadêmicas, dar elasticidade e amplitude aos processos técnicos, para que a ideia se transubstancie, sintética e livre na carne fresca do Verbo, sem deitá-la, antes, no leito de Procusto dos tratados de versificação. Queremos exprimir nossa mais livre espontaneidade, dentro da mais espontânea liberdade. Ser, como somos, sinceros, sem artificialismos, sem contorcionismos, sem escolas. Sonorizar no ritmo original e profundo tudo o que reboe nas nossas almas de sino, carrilhonando as aleluias das nossas íntimas páscoas, dobrando a angústia de nossos lutos (DEL PICCHIA, 1983, p. 332).

A despeito da retórica inflamada do palestrante, com momentos de impagável mau gosto, o que aí está dito pode ser traduzido na libertação quanto à metrificação e experimentação de novos processos técnicos, defesa da espontaneidade e da síntese e, interpretando um pouco, abertura do espírito às sugestões do ambiente e da atualidade. Para entender melhor os elementos técnicos defendidos pela prosa arrevesada de Menotti, podemos nos apoiar em A escrava que não é Isaura, de Mário de Andrade. O que Menotti chama de "mais livre espontaneidade" e "sinceridade" será descrito por Mário como "lirismo", um "estado ativo proveniente da comoção" (ANDRADE, 1980, p. 205). A esse estado de poesia subjetivo, que faz a propulsão da escrita poética, Mário chama de "impulsão lírica" ou "moto lírico", que nasceria no subconsciente, no "eu profundo". Os meios técnicos primários de expressão dessa espontaneidade/moto lírico são a "palavra solta" e a "associação de imagens". O resultado dessa relação entre impulso subjetivo/ subconsciente e seus meios técnicos é o recurso moderno por excelência: a expressão artística da simultaneidade, a montagem, a que Mário, professor de música, chamaria de "polifonismo". Ele enumera, então, as leis técnicas e estéticas da poesia modernista, que são, tecnicamente,

A Vida Moderna, em crônica de 23 de fevereiro de 1922, reproduz de modo paródico o ambiente da conferência de Menotti (apud BOAVENTURA, 2008, p. 265-286).

3. Oswald diz em seu depoimento de 1954 sobre o Modernismo: "O Correio Paulistano, órgão oficial do governo, ficou em matéria de arte e literatura uma pura subversão" (ANDRADE, 1992, p. 124). 
verso livre, rima livre, vitória do dicionário, e, esteticamente, substituição da ordem intelectual pela ordem subsconsciente, rapidez e síntese, polifonismo (ANDRADE, 1980, p. 225-226).

Depois da fala de Menotti, que acompanhamos, no que se refere à poesia, com o apoio do pensamento de Mário de Andrade, vieram as recitações. Dos poetas que recitaram ou foram recitados, quero chamar a atenção para as contradições que a aclimatação da vanguarda internacional provocava no nosso primeiro conjunto de poetas modernistas, em que entravam pelo menos três elementos fortes: a negação crítica da estética parnasiana, a ausência da poesia simbolista como presença objetiva e reconhecível pelo público leitor de poesia e, por fim, o contexto local que a poesia de vanguarda, principalmente a francesa de Apollinaire e Blaise Cendrars, encontrava em São Paulo. Essas contradições podem ser verificadas nas poesias de Agenor Barbosa, Tácito de Almeida, Luís Aranha e Mário de Andrade. São eles quatro poetas de São Paulo que tiveram obras divulgadas ao longo do ano de 1921 nos jornais (caso de Agenor Barbosa e Mário de Andrade) ou que as divulgaram depois da Semana, ao longo de 1922, na revista Klaxon (caso de Tácito de Almeida irmão de Guilherme de Almeida que assinava Carlos Alberto de Araújo-, Luís Aranha e Mário de Andrade).

Seguindo ainda uma última vez a fala de Menotti, veremos que o começo e o fim dela citam, sem nomear, o poeta Agenor Barbosa: "Pela estrada de rodagem da via láctea, os automóveis dos planetas correm vertiginosamente" (DEL PICCHIA, 1983, p. 327); essa era a frase de abertura da palestra, que evocava o poema "Canto Real da Estrada de Rodagem", bem como o final, quando fala dos "elementos da estética moderna, fragmentos de pedra em que construiremos, dia a dia, a Babel de nosso Sonho, no nosso desespero de exilados de um céu que fulge lá em cima, para o qual galgamos na ânsia devoradora de tocar com as mãos as estrelas!" (DEL PICCHIA, 1983, p. 334), faz referência ao poema "Os Pássaros de Aço", do mesmo Agenor. Essas referências não são arbitrárias, pois é Menotti quem lança o poeta, em sua coluna no Correio Paulistano, de 14 de abril de 1921, na crônica "Um Novo" (DEL PICCHIA, 1983, p. 213-217). Reproduz então o poema "O Que Eu Vi Nessa Noite", um fragmento de "Canto Real da Estrada de Rodagem" e um fragmento de "Vida Boêmia". Além deles, Oswald de Andrade, na crônica "Literatura Contemporânea", publicada em 12 de junho de 1921 no Jornal do Commercio, reproduz o poema "Os Pássaros de Aço" (apud BRITO, 1997, p. 239-240). Esses quatro poemas, dois inteiros e dois fragmentos, 
constituem a obra do poeta conhecida no contexto da Semana de 22 e que constaria de seu livro Poemas da vida e das cidades, anunciado por Menotti ${ }^{4}$.

O que se destaca desses poemas são os resultados canhestros da tentativa de unir sugestões modernas e urbanas a uma inspiração simbolista, como se lê nos versos da primeira estrofe de "Os Pássaros de Aço": "No aeródromo, o aeroplano / Subia, triunfal, na tarde clara, / Grande e sonoro, como o Sonho humano!" (v. 1-3) (apud BRITO, 1983, p. 239). O poema contrapõe desejo de transcendência e referência sistemática à cidade de São Paulo e à tecnologia moderna. A manutenção da métrica, com o decassílabo sáfico fechando a estrofe, a letra maiúscula, a transcendência... É como se fosse Cruz e Sousa no aeroporto. Com o refrão "Ó bandeiras da audácia", que identifica o avanço técnicoindustrial com o "bandeirantismo" de São Paulo, o que constitui, diga-se de passagem, a chave mestra da propaganda modernizante de Menotti del Picchia, o poeta conjuga estrofes integralmente simbolistas, como: "De subir no seu Sonho e na sua Ânsia! / De ver tudo que acena na distância / E que, jamais, pôde atingir" (v. 50-53) (apud BRITO, 1983, p. 240). Em contraste com esse Simbolismo, há passagens impuras, que aumentam o interesse do poema, como: "Em semicírculos, como uma ave de rapina, / Subiu num rufo de motor / Dominador, / Pela amplidão dos céus, solitária e divina!" (v. 22-25) (apud BRITO, 1983, p. 239).

Embora essas tentativas estejam hoje muito ultrapassadas, elas revelam, justamente pelo modo explícito como aparecem os seus defeitos, um problema real para a poesia de então: como afirmar a estética moderna da rapidez e da simultaneidade sem perder a disciplina que foi aprendida no Parnasianismo e sem pular o Simbolismo e seus estágios, fingindo que ele nunca existiu? Em duas crônicas, Agenor Barbosa confirma esse problema, quando diz que "não é futurista, mas gostaria mesmo de ser, pois considera o futurismo plenamente de acordo com o mundo moderno" e pede para que não se esqueça a sua "formação simbolista" (apud GUELFI, 1987, p. 106). Ou seja, a demanda de atualização poética, que atendia pelo vago nome de "futurismo", não é suficientemente forte para eliminar suas inclinações subjetivas, criando, no confronto entre as duas fidelidades, uma poesia híbrida e, por isso,

4. Sobre o poeta há, além das crônicas de Menotti e Oswald, trecho de um panorama de Plínio Salgado. “A poesia em São Paulo" (apud BOAVENTURA, 20o8, p. 340-341); trecho do "Depoimento de Rubens Borba de Moraes" (apud AMARAL, 1979, p. 308) e comentário de Mário da Silva Brito (1983, p. 221-223). 
historicamente interessante, em que o aeroplano, "pássaro de aço / e pano", erguendo-se com seu ritmo novo e livre, que o poema tenta mimetizar, passa a comportar-se como um poeta simbolista, pois, como dizem os versos: "Subiu... e como alguém que perscruta o horizonte, / Vagou, sereno, pela imensa solidão, / Como se olhasse, ao longe, o perfil de algum monte..." (v. 26-28) (apud BRITO, 1983, p. 239).

O mesmo problema de Agenor Barbosa, que é o modo de conciliar sensibilidade simbolista e crepuscular com a sensibilidade que se impunha pela modernização técnica do mundo, é sentido por Tácito de Almeida. Mas Tácito, pelo livro que conhecemos, de publicação póstuma, O Túnel, escrito em 1922 e publicado somente em 1987 (ALMEIDA, 1987) ${ }^{5}$, busca liquidar a questão com uma coerência rigorosa e organiza o problema como rito de passagem, a que alude o título de seu livro. Antes de sua publicação, o que se conhecia de Tácito eram os quatro poemas de Klaxon, publicados nos números 2, 4, 6 e 8-9 ${ }^{6}$, em que o poeta oferece ainda uma recordação do Penumbrismo, como em "Salvar" (ARAUJO, 1972C, p. 6), mas, principalmente, se destaca como poeta criador de imagens ousadas, como esta que fascinou Mário de Andrade em A escrava...: "E o vento rasteiro / vestido de poeira / passa faminto como um cão / farejando a Terra...", de “A Mesma Tempestade”, publicado em Klaxon n. 4 (ARAUJO, 1972a, p. 6). Esse poema é, certamente, o mais bem realizado de Tácito, no sentido do nosso primeiríssimo Modernismo, pois se compõe todo de imagens novas e dinâmicas, com um verso polimétrico suficientemente dúctil para ser incorporado à força imagética da dicção.

Entretanto, "A Mesma Tempestade" é um ponto de chegada da obra do autor, que, como Agenor Barbosa e Luís Aranha, abandonou a literatura logo depois desse período de afirmação da nova poesia, que vai dos antecedentes da Semana (meados de 1921) ao fim de Klaxon (janeiro de 1923). Do que foi publicado de sua obra poética, não obstante, podese julgar que se trata de um autor dotado de aguda consciência de seu momento histórico-literário e que buscou afirmar a sua personalidade moderna por meio da consumação de sua sensibilidade crepuscular, de seu penumbrismo. O símbolo do "túnel”, que dá título a seu livro mais

5. Destaco o ensaio introdutório “Tácito Tempo de Passagem”, de Telê Porto Ancona Lopez, que acompanho de perto em minha argumentação (apud ALMEIDA, 1987, p. 7-36).

6. Os poemas aparecem sob autoria de Carlos Alberto de Araújo. Não se trata de um pseudônimo, mas de partes de seu nome completo, que era Carlos Tácito Alberto de Almeida Araújo. O objetivo do poeta era distanciar-se da identificação com o irmão Guilherme de Almeida, poeta que já gozava de prestígio à época. 
significativo e, como veremos, a um de seus principais poemas, éformulado com exatidão por outro poeta, que passou por processo semelhante ao de Tácito: Luís Aranha, que, em seu poema também denominado "O Túnel", chama essa "sombra hiante da morte" (o túnel) de "Garganta que assombra como a morte: / Treva entre duas vidas luminosas..." (ARANHA, 1984, p. 81). Ao pensar na obra de Tácito de Almeida com esse apoio simbólico trazido da poesia de Luís Aranha, percebemos que as duas vidas luminosas serão: o fin-de-siècle anterior ao Modernismo, estilo ao mesmo tempo crepuscular e elegante, que distingue socialmente o moço de fina sensibilidade apesar de, ou pour cause, separá-lo do turbilhão da vida pela sua hipersensitividade subjetiva; e a vida moderna, dinâmica e afirmativa, em que a sensibilidade é elemento de força em uma personalidade que usufrui dos avanços técnicos, sintoniza os ritmos novos e as imagens imprevistas da multiplicidade, que resultam num tipo de vida esportiva e pública.

O "túnel" de Tácito de Almeida, desse modo, será o momento entre as duas vidas e as duas poéticas, em que o encontro delas deve transfundir uma na outra. O primeiro estágio dessa simbologia é a justaposição, como em "Sourcier", poema de duas estrofes, em que a primeira é constituída de versos mais curtos e dinâmicos, com imagens fortes e modernas, enquanto na segunda predominam versos mais longos e meditativos, que esbatem em tom melancólico o dinamismo inicial. O próximo estágio é o contraste, como em "Crianças", em que o trem, chamado no poema de "comboio", é confrontado às cidadezinhas em que ele passa: "Rápido comboio... / Ó o ponto negro das cidades pobrezinhas, / sentadas como crianças, / tristemente, nos degraus mais baixos das montanhas..." (v. 7-11) (ALMEIDA, 1987, p. 48). A esse tom penumbrista sucede o contraste propriamente dito, em termos estéticos:

\section{RÁPIDO COMBOIO...}

E o mundo feliz, o mundo elétrico, cheio de brilho, cheio de luzes, cheio de noites alegres, o mundo feliz cheio de leitos!

Cidades pobrezinhas, pequeninas, que não poderão nunca mais crescer!...

Caminhos vermelhos e estreitos que lutam, que fogem, que sobem, caminhos que somem e só vão parar,

desfalecidamente, cada vez mais surdos, mais desertos, à porta gelada, gelada dos cemitérios...

(v. 29-39) (ALMEIDA, 1987, p. 49) 
Nenhum dos dois momentos desses versos - o que incorpora a euforia da tecnologia e da velocidade e o que olha de modo penumbrista e melancólico o interior que definha - está livre de um tom embotado e artificial, o que confina o poema em uma fatura poética muito fraca. Contudo, a questão central, a tentativa de fusão de Penumbrismo e Modernismo sob o signo deste último corrobora o interesse do poema, confirmado pelos versos finais da citação, em que o caminho esteticamente evanescente do poema é o caminho de morte da vida interiorana, suplantada pelo comboio. $\mathrm{O}$ poema em que essa consumação do Penumbrismo no Modernismo é mais bem realizada, tanto em termos simbólicos quanto poéticos, é "O Túnel”, que cito integralmente:

\section{O Túnel}

Viajar, viajar, varar veloz todos os verdes confundidos, rasgar mais a carne viva dos barrancos, desequilibrar as planícies pacíficas, sofrer as choupanas incompreensíveis,

5 violar as aldeias românticas, e de repente perfurar negramente as montanhas, como uma espada que entrasse na bainha...

Túnel...

10

15

20
A treva dos sonos, a treva dos túmulos, a treva que foi feita para a imobilidade!

Ó como é doloroso movimentar-se tanto nas trevas cilíndricas!

Trevas úmidas, para revelar as fotografias das paisagens anteriores!

Luz vermelha dos corações, luz que não fere!...

E no túnel frio, no túnel longo, ansiar pelos relevos ásperos, ásperos mas claros, das últimas pedras.

(ALMEIDA, 1987, p. 38)

O túnel está vinculado ao símbolo do trem, que viaja e também gera as imagens violentas da primeira estrofe: rasgar, violar, sofrer, perfurar. $\mathrm{O}$ ponto de chegada no poema é a treva, a treva do túnel, imagem de morte, 
expresso nos versos em recuo, cujo tom in extremis aparece no estertor do movimento dentro do túnel. Antes, entretanto, de confirmar a imagem da morte, nos últimos quatro versos do poema, há duas estrofes muito significativas, entre os versos em recuo e os versos finais (versos 14-17); aí, em tom de elegia, o passado, o que se perde quando se entra no túnel, é recuperado por uma técnica moderna: a fotografia. O momento mortal é transfigurado em um processo moderno de revelação fotográfica, do momento de escuridão, da "câmera obscura", à luz vermelha, que, além de procedimento técnico da revelação da fotografia, é também imagem do sangue de quem morre e imagem do afeto, do coração que sente. Transfigurado em fotografia, o passado, a paisagem anterior, possui uma sobrevida dentro do túnel, que fixa a morte do Penumbrismo, exposto à violência do trem que viaja. Fora do túnel, na outra ponta, essa vida vai conhecer principalmente a força soberana da vida moderna, das imagens rápidas e dos ritmos dinâmicos de "A mesma Tempestade". Desse modo, por deter e expor de maneira desenvolvida a necessidade de superação do estágio simbolista, em seu momento final, pode-se dizer que o livro O túnel é a "câmara ardente" do Penumbrismo brasileiro, cuja morte é necessária para o aparecimento da vitalidade moderna ${ }^{7}$.

O que na poesia de Tácito de Almeida de $O$ túnel é fixado na forma poética, em Cocktails (1922), publicado postumamente apenas em 1984, de Luís Aranha, é dividido em momentos separados e diferentes de uma obra poética. Do simbolista, pelo título e pela forma, "Canção das Névoas", passamos ao contraste de "O Túnel" e "O Trem”. Neste, a adesão à velocidade moderna é um programa declarado: "Tu és mais livre que meu pensamento / Entorpecido e lento" e "Oh trem! / Nada no espaço te detém! / Se vejo tua corrida brava / Meu pensamento / Tem um surto violento / Para seguir teu ímpeto de guerra / Até os confins da terra" (ARANHA, 1984, p. 79). Desse "surto violento" de rapidez desejado em "O Trem" desenvolvem-se suas principais realizações, os poemas longos: "Drogaria de Éter e de Sombra”, "Poema Giratório" e "Poema Pitágoras". $\mathrm{O}$ procedimento pelo qual o pensamento adquire a liberdade e a rapidez

7. Isso não quer dizer, obviamente, que o Penumbrismo tenha deixado de existir depois desse livro. Sabemos que ele continuou na poesia de Bandeira por longo tempo e em Ribeiro Couto praticamente por toda a sua obra poética, que acompanha e ultrapassa todo o Movimento Modernista, para me deter em apenas dois exemplos. O que quero dizer com minha análise de $O$ túnel é que, na lógica interna das transformações e rupturas formais que estão acontecendo na poesia paulista no contexto da Semana, o livro de Tácito de Almeida expõe de maneira modelar um processo que os modernistas mais renovadores levaram a cabo, como veremos na análise de Luís Aranha e do Mário de Andrade de Pauliceia desvairada. 
ansiadas é a incorporação da vanguarda francesa: os "Cocteau / Cendrars / Rimbaud cabaretier" do poema "Cocktail" ou, mais extensamente descrito nessa passagem de "Poema Giratório": "Um dia uma revista / Conheci então Cendrars / Apollinaire / Spire / Vildrac / Duhamel / Todos os literatos modernos" (ARANHA, 1984, p. 66). Desses modernos, seu interesse se direciona sobretudo à obra de Cendrars. Mário afirma, em seu texto sobre o poeta:

Os livros de Blaise Cendrars, de Max Jacob, de Apollinaire, de Cocteau que então estavam me chegando, muitas vezes era Luís Aranha quem os devorava primeiro [...] Blaise Cendrars explodiu de madrugada entre nós. Pra Luís Aranha então foi decisivo, pois dum passo do Du Monde Entier, em que o poeta se entrega sem mais controle intelectual nenhum à associação de imagens, Luís Aranha faz agora o princípio básico de sua poética (ANDRADE, 2002, p. 71-72).

Com a vanguarda francesa, então, Cendrars à frente, Luís Aranha afia o seu procedimento central, reconhecido por toda a sua pequena fortuna crítica: a associação de imagens ${ }^{8}$. De seu prodigioso associacionismo dão testemunho os três poemas longos citados, bem como o interessante "Poema Pneumático". Se nos detivéssemos, no entanto, no aperfeiçoamento desse processo de associação, dificilmente venceríamos a ideia de que Luís Aranha se trata de um bom aluno brasileiro de Cendrars, estendendo, dessa forma, o elemento "preparatoriano" de sua poesia, estudado por Mário de Andrade. Contudo, há uma demanda no programa internacional da vanguarda literária que faz com que, se uma estética é integralmente incorporada, ela dialeticamente se transforme, pois, como diz Mário: "Nosso atualismo é consequência direta da observação da realidade contemporânea” (ANDRADE, 2002, p. 6o). Nesse caso, como a poesia de Luís Aranha se abre para esse real paulistano que subjaz, de modo dialético, ao programa da vanguarda? A resposta encontraremos em "Drogaria de Éter e de Sombra”, longo poema de 450 versos. Aí o "realismo psicológico", ou seja, a associação livre entre movimentos subjetivos e sugestões externas, absorve um aspecto biográfico da vida do poeta: o fato de ele ter sido empregado em uma drogaria, uma farmácia da Rua São Bento, centro de São Paulo. Das dissonâncias entre a vida comezinha e trivial de empregado de drogaria e o cosmopolitismo da vanguarda francesa é composto o longo poema em questão.

8. A fortuna crítica do poeta está em parte reproduzida e integralmente listada em seu único livro (ARANHA, 1984, p. 107-143). 
O começo do poema é radical. Seus primeiros 17 versos são a transcrição de anúncios, reais ou imaginários, da tabuleta da farmácia. $\mathrm{O}$ conflito já está posto, pois a poesia da vida moderna, sucinta, telegráfica, simultânea, sintética, que se utiliza da montagem de métodos jornalísticos e cinematográficos (GRUNEWALD apud ARANHA, 1984, p. 120-125), se reduz à tabuleta de uma farmácia, "gruta de sombra" no "triângulo de sol e ouro" (v. 39-4o) (ARANHA, 1984, p. 26). "Triângulo", no caso, é o encontro das ruas São Bento, XV de Novembro e Direita, incluindo a Praça Antônio Prado, centro financeiro da São Paulo de 1920. O conflito enunciado nos primeiros 17 versos se desdobra nos três seguintes: "Eu era poeta... / Mas o prestígio burguês dessa tabuleta / Explodiu na minha alma como uma granada" (v. 18-2o) (ARANHA, 1984, p. 26). São três versos que indicam o caminho que o poema vai seguir. $\mathrm{O}$ ideal convencional de poeta do Brasil de então é o de um artista requintado e elevado, acima das coisas cotidianas. É esse ideal que o impacto simultaneísta da tabuleta burguesa rompe. "Rompe" não é bem a palavra, já que o poeta diz: "explode como uma granada”. A intensificação imagética é significativa, pois Luís Aranha irá, por meio da associação livre, compensar a trivialidade da sua vida de empregado de farmácia pelo uso acelerado e intensivo de um imaginário cosmopolita, de que fazem parte arroubos corajosos, ambientações guerreiras, viagens e romances pelo mundo e pela história, enfim, uma encantadora compensação imaginária a que a realidade paulistana e farmacêutica faz dissonância periódica.

Um ponto de alta realização desse conflito se dá entre os versos 368 e 384, em que uma mulher de origem asiática, inicialmente chamada de chinesa e depois de japonesa, se senta ao lado do poeta no bonde. Um fluxo de associações que percorrem história e paisagem da China e depois do Japão se apodera dos versos, até chegar a uma declaração de amor em estilo romântico, no interior da qual irrompe, por associação rímica, seu universo de droguista/farmacêutico. Leiamos:

\author{
Amo-te como amo a primavera \\ As cerejeiras de rosa e de neve \\ O espelho corrente do regato \\ A flor do cacto \\ $\mathrm{O}$ aroma verde dos matos \\ Carbonato \\ Fosfato \\ Citrato \\ Azotato \\ Acetato \\ Nitrato \\ Sulfato
}




\section{Clorato}

Tartrato

Silicato

E o poder colossal de um sindicato

De drogas!...

(ARANHA, 1984, p. 38-39)

Por incorporar à exaustão o procedimento cendrarsiano da associação livre, Luís Aranha revela dialeticamente a contradição brasileira, especificamente paulista, da aclimatação da vanguarda francesa e criação da poesia modernista brasileira. Nessa contradição, o seu poema "Drogaria de Éter e de Sombra" descobre o dado local e o contexto brasileiro de forma irônica, embora não necessariamente crítica. Dada a abrangência de referências e sua diversidade estilística, que incorpora anúncios de tabuleta, associações livres, lirismo romântico e até inclui haicais dentro do poema longo, tudo isso exposto numa fluente dicção coloquial, podemos dizer que "Drogaria de Éter e de Sombra" rivaliza com os melhores poemas de Pauliceia desvairada como o melhor poema desse primeiríssimo momento da poesia modernista brasileira.

Se, por um lado, a poesia modernista de 1921-1922 tenta superar aceleradamente o Simbolismo a partir de dentro, por outro, ela se abre ao dado local e ao contexto brasileiro, seja pela referência que faz Agenor Barbosa à São Paulo que se urbaniza e incorpora novas tecnologias em "Os Pássaros de Aço", seja pelas cidadezinhas do interior de Tácito de Almeida ou ainda pelo conflito entre cotidiano trivial e aceleração cosmopolita em "Drogaria de Éter e de Sombra", de Luís Aranha. Essas duas questões vão ter a sua configuração poética mais ousada e sistemática em Pauliceia desvairada (1922), de Mário de Andrade. É Oswald de Andrade quem diz, em seu depoimento de 1954, sobre a Semana: "O movimento engrossava. Mas sem a publicação de Pauliceia desvairada, [...] nada se teria precisado" (ANDRADE, 1992, p. 122). Com efeito, a novidade desse livro foi sentida por todo o grupo modernista e, entre meados de 1921 e começo de 1923, o livro foi comentado na imprensa por Oswald de Andrade (apud BRITO, 1997, p. 223-227), Menotti del Picchia (1983, p. 357-358), Luís Aranha (1922, p. 11), Tácito de Almeida (ARAUJO, 1972b, p. 12-14), Sérgio Milliet (apud BOAVENTURA, 2008, p. 163-175), Manuel Bandeira (2008, p. 23-27), Ronald de Carvalho (apud BATISTA; LOPEZ; LIMA, 1972, p. 197-200) e Tristão de Ataíde (apud BATISTA;

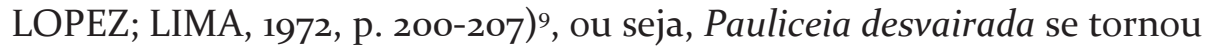

9. Dada a perspectiva imanente deste ensaio, vou me ater somente a essa bibliografia da recepção imediata do livro, pois seria extenso e, até certo ponto, desnecessário elencar e desenvolver aqui os demais estudos que a obra recebeu. 
rapidamente um patrimônio coletivo do grupo modernista. O que se sentia nesse momento era o aspecto de imprevisto do livro, de síntese inesperada do que estava no ar. Tácito notou a presença da cidade, "da cidade-rua, da cidade-pública” (ARAUJO, 1972b, p. 13); Milliet percebeu o choque: "não há nas suas obras quase nenhum verso que não seja uma metáfora ousada e sugestiva" (apud BOAVENTURA, 2008, p. 171); Tristão, na trilha de Milliet, apontou o contraste: "a sua inspiração, como me parece, nasce quase sempre de um contraste" (apud BATISTA; LOPEZ; LIMA, 1972, p. 202); por fim, Bandeira nota a adesão ao "simultaneísmo" da arte moderna e, ao mesmo tempo, o apego tão radical à concretude da cidade que o livro "em muitos pontos se torna incompreensível a quem desconhece o ambiente de São Paulo” (BANDEIRA, 2008, p. 26).

Nos dias de hoje, é necessário um esforço razoável, embora salutar, para compreender o que foi a Pauliceia desvairada nesses primeiros anos, porque, com a evolução impressionante da poesia brasileira nas décadas subsequentes, o leitor habitual de poesia nos anos 2010 há de ler o livro de Mário e perceber sobretudo o hibridismo estético, os arroubos pouco justificados, um tom artificial, um fundo de moralismo maternal, algum radicalismo ingênuo e referências criptografadas de uma São Paulo que sumiu no tempo. Tanto melhor para a poesia brasileira. Mas o fato é que tal desenvolvimento e depuração da poesia modernista dependeram, em seu momento inicial, da Pauliceia desvairada, o que põe para a crítica a seguinte questão: como e por que esse livro de Mário se impôs com tal autoridade nesses primeiros anos do movimento?

Uma resposta possível, da perspectiva deste ensaio, é o acúmulo de questões que o livro traz: negação crítica do Parnasianismo, superação acelerada do Simbolismo, tentativa de aclimatação da estética de Whitman e Verhaeren, das vanguardas do futurismo italiano, do expressionismo alemão e da vanguarda francesa de ApollinaireCendrars, ou seja, do simultaneísmo e do psicologismo francês, muito divulgados pela revista L'Esprit Nouveau, tentativa de configuração da modernização contraditória de São Paulo, a um tempo cosmopolita e provinciana, do que deriva a expressão psicológica das violências sofridas por um ambiente majoritariamente mesquinho, que tachava a arte moderna de loucura, cabotinismo e patologia, bem como encharcava o poeta de vexames, recriminações e ridicularizações. Resumindo: o problema da aclimatação da arte moderna, com a necessidade de superar o Parnasianismo e o Simbolismo a partir de dentro, e da referência ao dado local e ao contexto brasileiro era compactado em um esforço de síntese. Esse conjunto de problemas pode ser verificado, em diagrama, pela leitura do poema que escandalizou a cidade quando Oswald o 
publicou em sua coluna do Jornal do Commercio, inserido no texto "O Meu Poeta Futurista" (27/05/1921). Trata-se do poema "Tu”, que aqui transcrevo de acordo com a versão publicada em livro:

\section{Tu}

Morrente chama esgalga,

Mais morta inda no espírito!

Espírito de fidalga,

Que vive dum bocejo entre dois galanteios

5

E de longe em longe uma chávena da treva bem forte!

Mulher mais longa

Que os pasmos alucinados

Das torres de São Bento!

Mulher feita de asfalto e lamas de várzea,

10 Toda insultos nos olhos,

Toda convite nessa boca louca de rubores!

Costureirinha de São Paulo,

Îtalo-franco-luso-brasílico-saxônica,

Gosto dos seus crepusculares,

15 Crepusculares e por isso mais ardentes,

Bandeirantemente!

Lady Macbeth feita de névoa fina,

Pura neblina da manhã!

Mulher que és minha madrasta e minha mãe!

20

Trituração ascencional dos meus sentidos!

Risco de aeroplano entre Mogi e Paris!

Pura neblina da manhã!

Gosto dos teus desejos de crime turco

E das tuas ambições retorcidas como roubos!

25 Amo-te de pesadelos taciturnos,

Materialização da Canaã do meu Poe...

Never more!

Emílio de Menezes insultou a memória do meu Poe...

Oh! Incendiária dos meus aléns sonoros!

$30 \quad$ Tu és o meu gato preto!

Tu me esmagaste nas paredes do meu sonho!

Este sonho medonho!

E serás sempre, morrente chama esgalga,

Meio fidalga, meio barregã,

As alucinações crucificantes

De todas as auroras do meu jardim! 
Embora não seja o caso de analisar detalhadamente o poema, pode-se perceber as confluências estéticas que nele atuam. Há 6 dodecassílabos (v. 4, 9, 15, 20, 26 e 31), sendo 3 deles alexandrinos clássicos e 3 acentuados na quarta e oitava sílabas. Há também dois decassílabos heroicos (v. 34 e 35). São 8 versos de metrificação tradicional num total de 36 . Isso significa, principalmente no caso dos alexandrinos espalhados pelo poema, que o Parnasianismo não precisava ser totalmente demolido, ele precisava ser negado criticamente, aproveitando-se, porventura, no momento certo, um resíduo de seu legado. No caso do Simbolismo, a questão é mais tensionada, pois, de modo geral, o poema é marcadamente simbolista, especificamente do Simbolismo de Alphonsus de Guimaraens, admirado por Mário, que o visitou em 1919 e cujos poemas eram divulgados em Papel e Tinta (1920-1921), periódico paulista em que primeiro se agruparam os modernistas. Há profusão de características simbolistas no poema. O primeiro verso é nitidamente alphonsino, com o seu sugestivo e raro "esgalga". Além dele, observamos momentos de tom espiritualizado, de sentido ascensional, a imagem repetida do crepúsculo, o uso de advérbio longo terminando com o sufixo -mente ("bandeirantemente"), ambientação de mistério que remonta ao Romantismo de Poe, névoa, neblina e sonho. A situação se torna mais evidente se comparamos a versão de Pauliceia desvairada com a transcrita no Jornal do Commercio, em que está escrito "Sonho" e "Chama", com maiúscula, além de haver 8 versos terminados em reticências (apud BRITO, 1997, p. 226-227), contra apenas dois mantidos no livro. Se a estética simbolista tivesse se afirmado no espaço público de nosso ambiente literário e fosse de conhecimento dos leitores habituais de poesia, dificilmente "Tu" causaria tamanho escândalo.

Com isso, chegamos à opinião que Mário emite em carta de 1924 a Drummond, de que Pauliceia desvairada é uma "mistura de simbolismo até parnasianismo, e modernismo que ninguém aqui percebeu" (ANDRADE apud SANTIAGO, 2002, p. 72). Mas a novidade do poema é que a estética modernista irrompe de dentro da estética simbolista, explodindo seus limites, como a mostrar a acelerada troca de pele em que, no contexto brasileiro, o Simbolismo se torna Modernismo. Vejamos, então, a primeira estrofe. Os três primeiros versos são sextetos de ritmos pares e vocabulário raro e antiquado, com a repetição musicalizante de "espírito". No quarto verso, duas palavras de registro vulgar quebram o tom: "bocejo" e "galanteio", mas dentro de uma métrica de alexandrino com cesura tradicional. Só no último verso da estrofe é que um verso livre e inumerável subverte o ritmo e introduz uma imagem imprevista, a "chávena de treva bem forte". A própria imagem entra nesse processo 
de transmutação, pois de elementos caros ao Simbolismo, a palavra rara "chávena" e a imagem da "treva", o poeta faz uma metáfora do café! E com o café entra no poema a cidade de São Paulo no que ela tem de mais fundamental: a sua base econômica e o seu símbolo convencional de grandeza.

A configuração da primeira estrofe se repete sistematicamente no poema. Na segunda, por exemplo, entre a espiritual "mulher mais longa" e as religiosas "torres de São Bento", há os "pasmos alucinados", a imagem forte e dissonante. $E$ às torres ainda segue a mulher contraditoriamente feita "de asfalto e de lamas de várzea". A referência moderna, o asfalto, já entra no poema contrastada, unida às lamas da várzea. Contudo, depois da segunda estrofe, define-se quem é a mulher do poema: a mulher é identificada à cidade de São Paulo, pois é vestida com as imagens da cidade. Por meio de referências a São Paulo, ou seja, pela incorporação do dado local e do contexto nacional, mediado pelo regional, nesse caso, a poesia modernista pode romper com mais segurança os limites do Simbolismo a partir de dentro e se impor como estética nova. Note-se ainda como isso ocorre em um procedimento recorrente do Simbolismo: "bandeirantemente" não reproduz, como naquela estética, uma ideia vaga e frouxa pelo alongamento do advérbio formado de adjetivo; ao contrário, o sentido da construção de Mário é o da dissonância, pois a referencialidade paulista é o avesso da vaga espiritualização, é a concretude trivial, cujo resultado no poema é um tom meio vago, meio jocoso. A construção adverbial é, como diz outro achado de expressão contrastiva, o verso 34, "meio fidalga, meio barregã". Por fim, uma última imagem para mostrar como Mário transforma a "pura neblina da manhã" em "todas as auroras do meu jardim". Veja-se, na quarta estrofe, os versos: "Trituração ascencional dos meus sentidos! / Risco de aeroplano entre Mogi e Paris!". Novamente, da expressão simbolista se desdobra uma imagem moderna dissonante. Mas é notável que aqui, em que a oposição seria mais elementarmente radical, a ascensão espiritual $v s$. a ascensão do aeroplano, Mário matiza contrastivamente o último termo: o aeroplano une Mogi a Paris, ou seja, a tecnologia moderna que une São Paulo a Paris possui essa dissonância interna, a referência brasileira é a muito pouco cosmopolita Mogi das Cruzes (para o contexto da época, nada contra Mogi - aliás, a escolha da palavra se deve certamente ao compasso dissílabo rimado Mogi/Paris, principalmente quando se pensa na sonoridade desta última lida em francês). Com esse verso, é como se Mário de Andrade operasse para a poesia brasileira o processo contraditório de aclimatação e adequação daquela primeira junção canhestra de "aeroplano" e "Sonho humano" que lemos em "Os Pássaros 
de Aço", de Agenor Barbosa.

Ao seguir as obras dos poetas presentes na Semana de Arte Moderna, seja de corpo presente, seja pela presença poética, verifica-se que é possível descobrir certa lógica nos problemas que os poemas mais originais de então se colocam. Dos poemas de transição, principalmente de Ribeiro Couto, Manuel Bandeira, Guilherme de Almeida e Ronald de Carvalho, passamos ao confronto entre estética de vanguarda e sistema literário brasileiro, no período entre 1921 e 1922, caracterizado sobretudo pela predominância provinciana e disciplinar da poética parnasiana. A ruptura poética precisava, nessa conjuntura, postular o Simbolismo no momento mesmo em que o ultrapassava esteticamente, transmutando-o em Modernismo. A isso se soma a abertura ao dado local e ao contexto nacional, que incorpora em estado latente a referência brasileira, o que prepara o caminho para o nacionalismo poético imediatamente posterior. A conjugação dessas questões propõe a colocação e o desenvolvimento de uma problemática: como criar uma poesia modernista brasileira original e pertinente. $\mathrm{O}$ resultado é a internalização, pela poesia brasileira, de uma dinâmica própria, em que as contradições da poesia internacional se tornam parte de um debate artístico coletivo e público sobre a sociedade e o país, que, por sua vez, se tornam temas de experimentação poética. Esse resultado é principalmente o "Manifesto da Poesia Pau-Brasil", de Oswald de Andrade, e o poema "Noturno de Belo Horizonte", de Mário, ambos de 1924, em que se propõe e realiza a absorção integral da poesia modernista em questões brasileiras. Essa plataforma experimental e nacionalista, proposta e executada primeiro por Oswald e logo em seguida desenvolvida por Mário, por sua vez, disponibiliza os programas, procedimentos e contradições que, individualmente pensados e elaborados, culminará na "poesia em 1930": a poesia modernista de Bandeira, Drummond e Murilo Mendes.

\section{REFERÊNCIAS BIBLIOGRÁFICAS}

ALMEIDA, Tácito de. Túnel e poesias modernistas-1922/1923. Estabelecimento de texto e estudo de Telê Porto Ancona Lopez. São Paulo: Art Editora, 1987.

AMARAL, Aracy. Artes plásticas na Semana de 22. São Paulo: Perspectiva, 1979.

ANDRADE, Mário de. A escrava que não é Isaura. Obra imatura. Belo Horizonte: Itatiaia, 1980 .

Poesias completas. Edição crítica de Diléa Zanotto Manfio. Belo Horizonte: Itatiaia; São Paulo: Edusp, 1987.

. Aspectos da literatura brasileira. Belo Horizonte: Itatiaia, 2002.

ANDRADE, Oswald de. Modernismo. Estética e política. São Paulo: Globo, 1992. 
ARANHA, Graça. A emoção estética na arte moderna. Obra completa. Rio de Janeiro: Instituto Nacional do Livro, 1969.

ARANHA, Luís. Cocktails. Organização de Nelson Ascher e pesquisa de Rui Moreira. São Paulo: Brasiliense, 1984.

. Paulicèa Desvairada. Klaxon: mensário de arte moderna. São Paulo, n. 4, p. 11, agosto de 1922. In: KLAXON - mensário de arte moderna. Edição fac-similar (192223). São Paulo: Livraria Martins, 1972.

ARAUJO, Carlos Alberto de [Tácito de Almeida]. A mesma tempestade. Klaxon: mensário de arte moderna. São Paulo, n. 4, p. 6, agosto de 1922. In: KLAXON - mensário de arte moderna. Edição fac-similar (1922-23). São Paulo: Livraria Martins, 1972a.

. Paulicea desvairada. Klaxon: mensário de arte moderna. São Paulo, n. 7, p. 12-14, novembro de 1922. In: KLAXON - mensário de arte moderna. Edição fac-similar (1922-23). São Paulo: Livraria Martins, 1972b.

. Salvar. Klaxon: mensário de arte moderna. São Paulo, n. 6, p. 6, outubro de 1922. In: KLAXON - mensário de arte moderna. Edição fac-similar (1922-23). São Paulo: Livraria Martins, 1972c.

BANDEIRA, Manuel. Crônicas inéditas I. São Paulo: Cosac Naify, 2008.

BATISTA, Marta Rossetti; LOPEZ, Telê Porto Ancona; LIMA, Yone Soares de. Brasil: $1^{\circ}$ tempo modernista-1917/1929. Documentação. São Paulo: IEB, 1972.

BOAVENTURA, Maria Eugênia (Org.). 22 por 22: a Semana de Arte Moderna vista pelos seus contemporâneos. São Paulo: Edusp, 2008.

BRITO, Mário da Silva. História do Modernismo brasileiro I. Antecedentes da Semana de Arte Moderna. Rio de Janeiro: Civilização Brasileira, 1997.

CARVALHO, Ronald de. O espelho de Ariel e poemas escolhidos. Rio de Janeiro: Nova Aguilar; Brasília, INL, 1976.

DEL PICCHIA, Menotti del. O Gedeão do Modernismo: 1920-1922. Seleção e organização de Yoshie Sakiyama Barreirinhas. Rio de Janeiro: Civilização Brasileira; São Paulo: Secretaria de Estado da Cultura 1983.

GOLDSTEIN, Norma. Do Penumbrismo ao Modernismo: o primeiro Bandeira e outros poetas significativos. São Paulo: Ática, 1983.

GUELFI, Maria Lúcia Fernandes. Novíssima. Contribuição para o estudo do Modernismo. São Paulo: IEB, 1987.

KLAXON - mensário de Arte moderna. Edição fac-similar (1922-23). São Paulo: Livraria Martins, 1972.

SANTIAGO, Silviano (Org.). Carlos \& Mário. Correspondência de Carlos Drummond de Andrade e Mário de Andrade. Rio de Janeiro: Bem-Te-Vi, 2002.

SCHWARTZ, Jorge (Org.). Caixa modernista. São Paulo; Minas Gerais: Edusp; Imprensa Oficial; Editora da UFMG, 2003. 